Journal of Educational

Technology \& Online Learning

Volume 4 | Issue 2 | 2021

http://dergipark.org.tr/jetol

\title{
Trend of distance education research in the covid-19 period: A bibliometric and content analysis
}

\author{
Mehmet Yavuz $^{\text {a* }}$ (D), Bünyami Kayalı ${ }^{\text {b }}$, Özgür Tutal c ${ }^{\text {(D) }}$ \\ ${ }^{a}$ Bingol University, Turkey. \\ b Bayburt University, Turkey. \\ c Ministry of National Education, Turkey.
}

Suggested citation: Yavuz, M., Kayal1, B. \& Tutal, Ö. (2021). Trend of distance education research in the covid-19 period: A bibliometric and content analysis. Journal of Educational Technology \& Online Learning, 4(2), 256-279.

\begin{tabular}{ll}
\hline Article Info & Abstract \\
\cline { 2 - 3 } Keywords: & $\begin{array}{l}\text { The study aims to reveal the studies' profile for distance education activities in the Covid- } \\
19 \text { period. For this purpose, bibliometric analysis and content analysis were used together } \\
\text { in the study. Within the scope of the study, 220 studies were selected in the Web of } \\
\text { Distance education } \\
\text { Bibliometric analysis } \\
\text { Content analysis }\end{array} \quad \begin{array}{l}\text { Science database to access the articles. Within the scope of bibliometric analysis, the } \\
\text { most used keywords, the most cited journals, the most publishing journals, the most } \\
\text { publishing countries and the most cited authors were analyzed with the VOSViewer } \\
\text { program. In content analysis, methodological trends (method, sample size, data } \\
\text { collection tool, data analysis type) used in the studies were examined. As a result of the } \\
\text { research, the most publications were made in the last quarter of 2020, 16\% of the studies } \\
\text { were single-author and the quantitative research method was the most preferred (40\%), } \\
\text { the sample was mostly university students (n=78). It was observed that it was clustered } \\
\text { between 0-100 intervals, the most frequently used questionnaire (n=105) as the data } \\
\text { collection tool, and the descriptive-quantitative analysis method (40\%) was used as the } \\
\text { data analysis method. Also, the most publications are made in America and China, the } \\
\text { most used keywords are "covid-19", "online education" and "distance education", the } \\
\text { most cited authors are Chen, Cong, Peng and Yang, and finally It has been observed that } \\
\text { the highly cited journal has Sustainability. }\end{array}$ \\
Research Article &
\end{tabular}

\section{Introduction}

The virus (Covid-19), which first appeared in Wuhan, capital of China's Hubei region, in December 2019, quickly became a pandemic and affected the whole world. The virus, which affects all areas of life, especially social and economic activities, has brought life to a complete standstill except for some essential services. The adverse effects of the pandemic have manifested themselves in the field of education as well as in all areas and all countries globally; formal education has been suspended in whole or in part. Considering the data released by UNESCO (2020), as of April 2020, schools were completely closed in approximately 190 countries around the world, while schools were partially or regionally closed in four countries due to the pandemic. This situation forced approximately $91 \%$ of students at all educational levels to face the negative effects of the pandemic, which corresponds to more than 1.5 billion students. Nevertheless, the number of teachers who were adversely affected by this process was announced as 65 million (TTF 2030, 2020).

\footnotetext{
* Corresponding author: Bingol University, Turkey.

e-mail addresses: yavuz.mehmet21@gmail.com
} 
Immediately after the first shock of the pandemic was overcome, the countries continued their education activities with alternative methods in order to minimize learning losses by continuing their educational activities and to help students cope with the negative effects of the pandemic. Distance education-based solutions come first among alternative methods. Through the synchronous-asynchronous applications used on television and radio broadcasts, internet-supported computers and mobile devices, both educational activities were continued and students were tried to be prevented from being completely detached from the education process (Aydin, 2020). In contrast to the planned distance education activities, remote educational activities carried out in the crisis periods such as war and pandemic in the crisis has revealed the concept of "emergency distance teaching" (Hodges et al., 2020; Smith, 2020). The temporary realization of the process was to be reverted to the decision as a result of the fact that the fact that it is realized under different conditions, resulting in different objectives and dynamics, resulting in different ways of remote education and online education concepts. The presence of all these differences has increased future public health and safety concerns due to natural disasters such as fires, hurricanes and polar vortex in recent years (Samson, 2020) further increased the interests of the researchers. During this period, academic studies in education generally focused on distance education activities during the pandemic process (Aristovnik et al., 2020). When the literature is examined, Covid applications in different education levels (Adom, 2020; Fiş Erümit, 2021; Nemec et al., 2020; Zamfir, 2020), teacher and student experiences (Chertakova et al., 2020; Elizabeth Noor Coutts et al., 2020; Yavuz et al., 2020; Kim, 2020), success, perception and attitude regarding the process (Gonçalves et al., 2020; Giovannella et al., 2020; Hamann et al., 2020; Wang et al., 2020) Studies for its identification (Bozkurt, 2020; Hodges et al., 2020; Samson, 2020) are encountered.

Sometimes, the excessive number of studies in the field brings along some problems. The results of studies on a subject may support each other as well as reveal conflicting results. Researchers doing research on any subject have difficulty accessing all of the studies on that subject or spend a lot of time to reach them (Göktaş et al., 2012). At this point, the results of content and meta-analysis made on studies in a certain field provide significant convenience to researchers (Selçuk et al., 2014). Bibliometric analysis is one of the methods of evaluating literature, such as the content analysis method (Falkingham \& Reeves, 1998) that helps to evaluate existing literature in a field. Bibliometrics is interested in examining various elements of academic publications with the help of numerical analyses and statistics. Bibliometric analyses may be descriptive in determining the number of articles published in a given year, or they may be evaluative in terms of citation analysis to reveal how an article affects the research that follows (McBurney \& Novak, 2002). Both methods are seen as necessary for guiding researchers on the issues mentioned.

\section{Literature}

Bibliometric analyses were carried out in various fields during the pandemic period. In this context, the study conducted by Kambhampati et al. (2020) found 6831 articles from the PubMed database using keyword searches and included 1802 publications covering human studies. In the review, it was stated that covid-19 related studies had been continuously increasing throughout the period. While it is stated that articles related to the pandemic were published in a total of 1430 journals, the most published journals among these are the British Medicine Journal (BMJ) (252 articles) and Journal of Medical Virology (186 articles). Another bibliometric review published during the pandemic period was carried out by Darsono et al. (2020). In this context, the researchers reached 1475 publications from the Scopus database. All articles were published between December 2019 and March 2020. As a result of the study, it was determined that 11 different types of publications were made, and Viruses Journal (74 articles) ranked first among the journals with the highest number of publications, followed by Lancet (50 articles) and Journal of Virology (39 articles). Besides, China took first place with 386 studies on country basis and Hong Kong University with 44 studies on institutional basis. In a similar review, Dehghanbanadaki et al. (2020) have reached 923 
studies on COVID-19 indexed in Scopus. China took first place with 348 studies based on the country, while the United States took second place with 160 studies. The Lancet and BMJ Research Ed were the journals with the highest number of publications. In terms of the institution, the University of Hong Kong and Huazhong University of Science and Technology shared first place with 30 publications. In other studies, on the subject (Chahrour et al., 2020; Chen, Guo, et al., 2020; Golinelli et al., 2020; Hamidah et al., 2020; Hossain, 2020; Hugar et al., 2020; Lou et al., 2020; Zhai et al., 2020; Zhou \& Chen, 2020) some variables such as authors, countries, languages, citations, institutions, sources, and publication types were examined. Most of the studies were generally carried out with a short time interval, with a concise literature or small sample. This situation may have caused contradictory results. To illustrate, Kambhampati et al. (2020) finds BMJ as the highest producing journal, while Darsono et al. (2020) found Lancet to be the most producing journal.

As a result, the bibliometric and content analysis studies that will be carried out for distance education activities in the Covid period are considered essential for determining the trend in this area. Also, it is believed that the data obtained from these studies will also make important contributions in directing subsequent research, developing publication policies, and guiding researchers in the field. In this context, 220 articles for distance education activities of the Covid-19 period in the Web of Science database were subjected to bibliometric and content analysis. In this direction, articles were examined in terms of month of publication, number of authors, number of pages, keywords, number of citations according to different variables (such as country, journal, author) and methodological trends. The current review aims to reveal the studies' profile for distance learning activities of the Covid-19 period. For this purpose, the review addressed the following research questions.

R.Q. 1. What is the distribution of distance education studies in the pandemic period by months?

R.Q. 2. What is the distribution of author numbers in distance education studies during the pandemic period?

R.Q. 3. What is the page number distribution of distance education studies in the pandemic period?

R.Q. 4. What is the distribution of studies on distance education in the pandemic period by country?

R.Q. 5. What is the distribution of the most commonly used keywords in the studies on distance education during the pandemic period?

R.Q. 6. Who are the most cited authors in the studies on distance education during the pandemic period?

R.Q. 7. What is the co-authorship relationship of the authors in the studies on distance education during the pandemic period?

R.Q. 8. Which journals have the highest number of publications and citations (citation and co-citation) in distance education studies during the pandemic period?

R.Q. 9. What are the methodological trends (method, sample, data collection tool and data analysis) of distance education studies in the pandemic period?

\section{Methodology}

The purpose of this review is to reveal the profile of the studies conducted for distance education activities in the Covid-19 period. To achieve this aim, bibliometric and content analysis methods were used together in the study. Content analysis can be defined as organizing, classifying, comparing textual expressions and drawing theoretical conclusions from texts (Cohen et al., 2007), or as any qualitative data reduction and interpretation effort to determine the basic consistency and meanings by taking qualitative studies in large 
numbers (Patton, 2014). On the other hand, Bibliometric analysis is based on following the studies on a specific subject and revealing the findings by analyzing these studies according to various characteristics (Marti-Parreno et al., 2016). Relevant publications in the Web of Science (WoS) database were included in the study to reach high-quality articles. In the scan conducted on 14/02/2021, key phrases were searched in the title, summary, or keyword sections by selecting the "Topic" option. Among the articles obtained after the search, English and open access articles with "ESCI, SCI-E, SSCI" indexes were included in the study. "Covid-19" and "distance learning" were used as keywords and phrases that evoke them. Keywords and inclusion criteria were presented in detail in Figure 1.

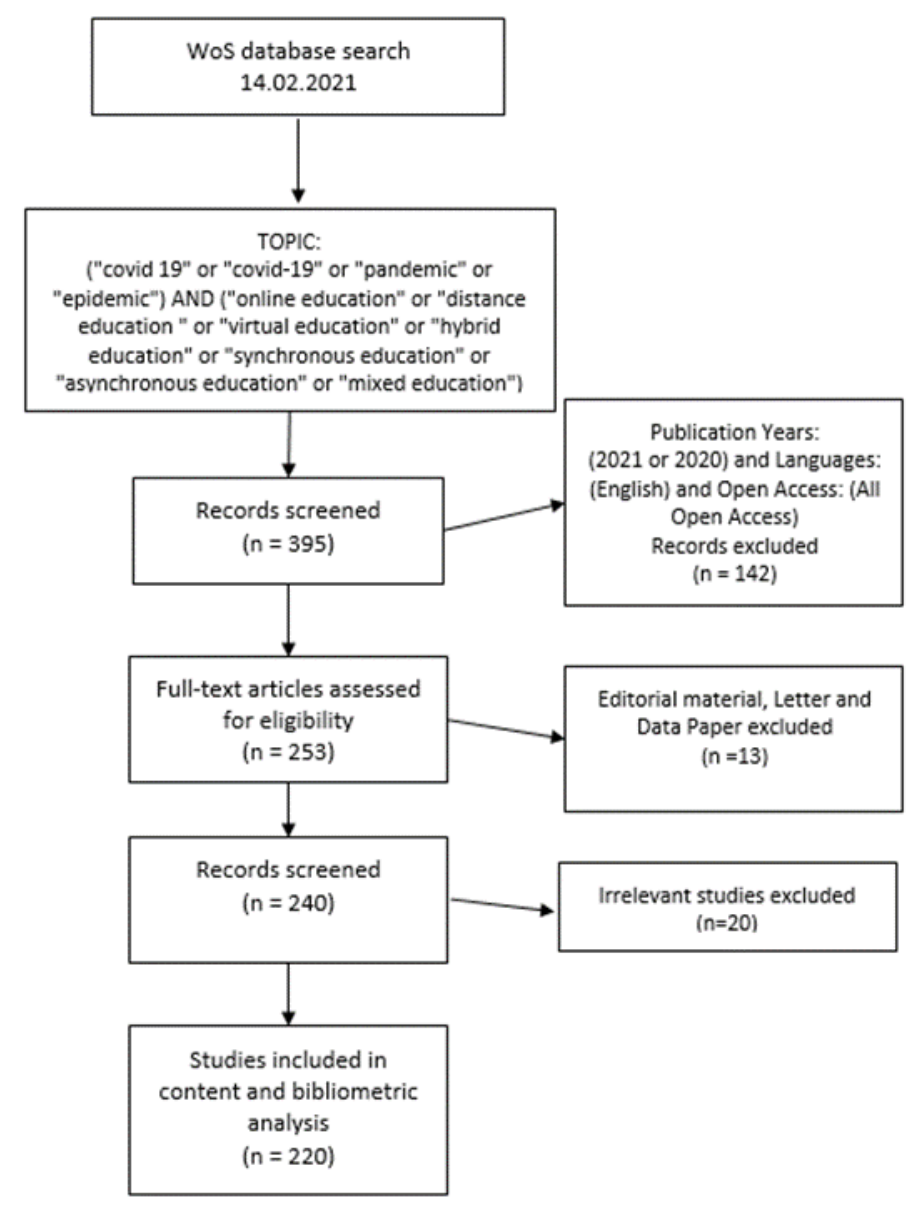

Figure 1. Article Selection: PRISMA Flow Diagram (Liberati et al., 2009)

\subsection{Data Collection Tool}

The researchers prepared a data collection form for data collection within the scope of the research. The data collection form has been prepared in MS Excel and consists of two parts. Titles such as the name of the study, author, page number, method used, sample group, sample number, data collection tool, data analysis method, publication year and month were included in the form. The purpose of examining the dimensions here is to reveal the methodological trends of the studies on distance education carried out in the Covid-19 period and draw a general framework by looking at them from a broad perspective. The data required for the bibliometric analysis part of the study was obtained from the WoS database. After determining all the articles to be included in the scope of the study, Export / Other File Formats / Full Record and Cited References options were checked, respectively. Then, File Format / Tab-delimited (Win) options were selected and the data was downloaded in txt file format. 


\subsection{Data Analysis}

\subsubsection{Content Analysis}

In the content analysis part of the review, 220 studies were examined by the first two authors. Each author examined 110 studies and the content analysis form was filled in this context. The other author has reviewed the content analysis form. After the data entry was completed, the entire form was reviewed by two authors and errors in coding were eliminated. Thus, the coding process was carried out by providing consensus. Finally, the data entries completed in the content analysis form were examined by the third author. Therefore, any errors were tried to be prevented and the validity and reliability of the analysis were tried to be ensured. In addition, in this study, the first two authors selected ten articles and encoded them separately. The consistency between this encoding was calculated as 90\%. According to Miller and Huberman (2019), the consistency between coders should be at least $80 \%$. Since the consistency in the study is over $80 \%$, it can be said that the consistency between coders is high.

\subsubsection{Bibliometric Analysis}

In addition to content analysis, the bibliometric analysis method was also used in the study. With bibliometric analysis, the most commonly used keywords, the most cited journals, the most published journals, the journals that published the most studies on the subject, the countries that did the most studies on the subject, the publication cooperation between countries, the keywords used and the relationship between them, the most cited authors, the relationship between the authors, the journals that were jointly cited and the most published areas were examined. The VOSViewer software, which is one of the widely used programs in the visualization of bibliometric networks (Artsin, 2020), was used to reveal the network visualization in the analysis.

\section{Findings}

The study aims to reveal the studies' profile for distance education activities in the Covid-19 period. Findings for the studies dealt with in this context were given in parallel with the research questions. Besides, descriptive information about the studies examined is presented in Table 1.

\section{Table 1.}

General information on the studies reviewed

\begin{tabular}{ll}
\hline Identification of Publications & Sonuç \\
\hline Number of publications & 220 \\
Total number of keywords & 724 \\
Average number of keywords & 3 \\
Years & $2020-2021$ \\
Total number of authors & 913 \\
Number of authors per publication & 4 \\
Total number of references & 7301 \\
Number of references per publication & 33 \\
Total number of citations & 365 \\
Number of citations per publication & 2 \\
Number of studies with a single author & 35 \\
Number of studies with multiple authors & 185 \\
Total number of pages & 2584 \\
Pages per publication & 12 \\
Number of countries where the article was published & 70 \\
Number of journals where the article was published & 161 \\
Total sample size & 198681 \\
\hline
\end{tabular}




\section{R.Q.1. Distribution of articles by months}

The first finding addressed within the context of content analysis is the publication year and month of the articles. It was seen that the articles were mainly published in the last quarter of 2020 (Figure 2).

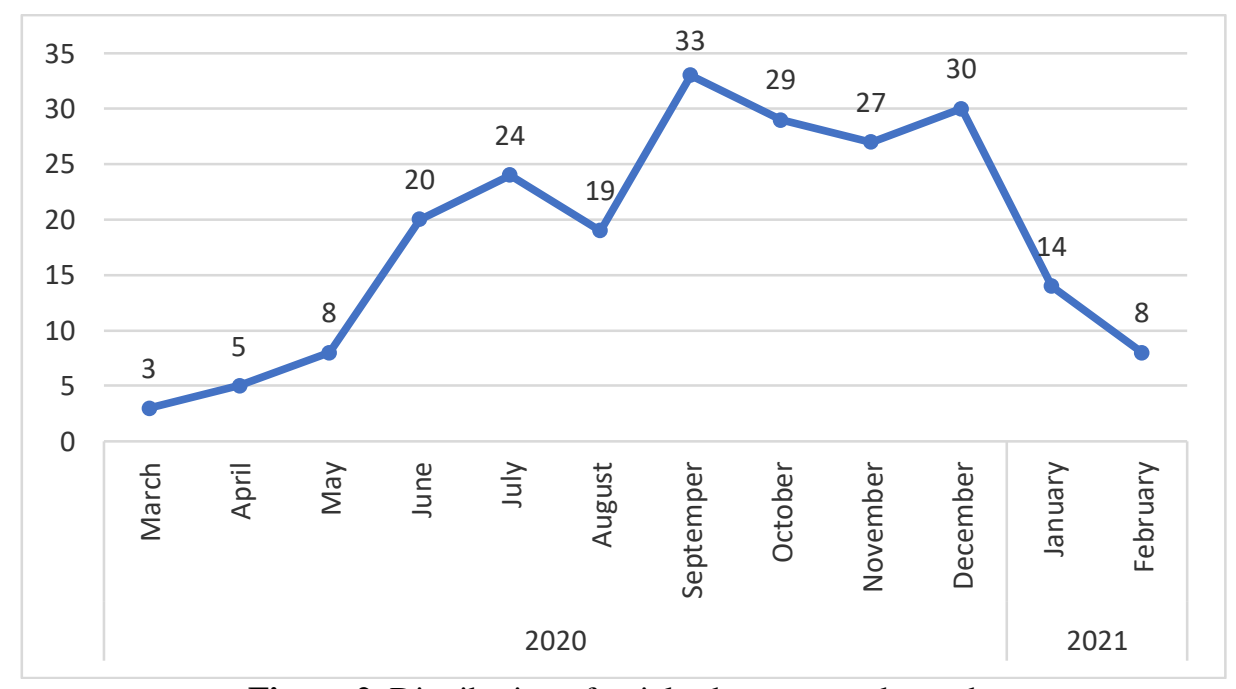

Figure 2. Distribution of articles by years and months

When Figure 2 examined it was seen that the articles were mostly published in September $(n=33)$, December $(n=30)$, October $(n=29)$ and November $(n=27)$. In other words, it can be said that the studies are stacked in the last quarter of 2020. However, at the beginning of both years, it is seen that the number of studies is in parallel and receives the lowest values.

\section{R.Q.2. Distribution of the number of authors in the studies}

The number of authors of the studies on distance education activities in the pandemic period was examined in the content analysis. In the review, it was seen that most of the studies had multiple authors. Findings about the number of authors are given in Figure 3.

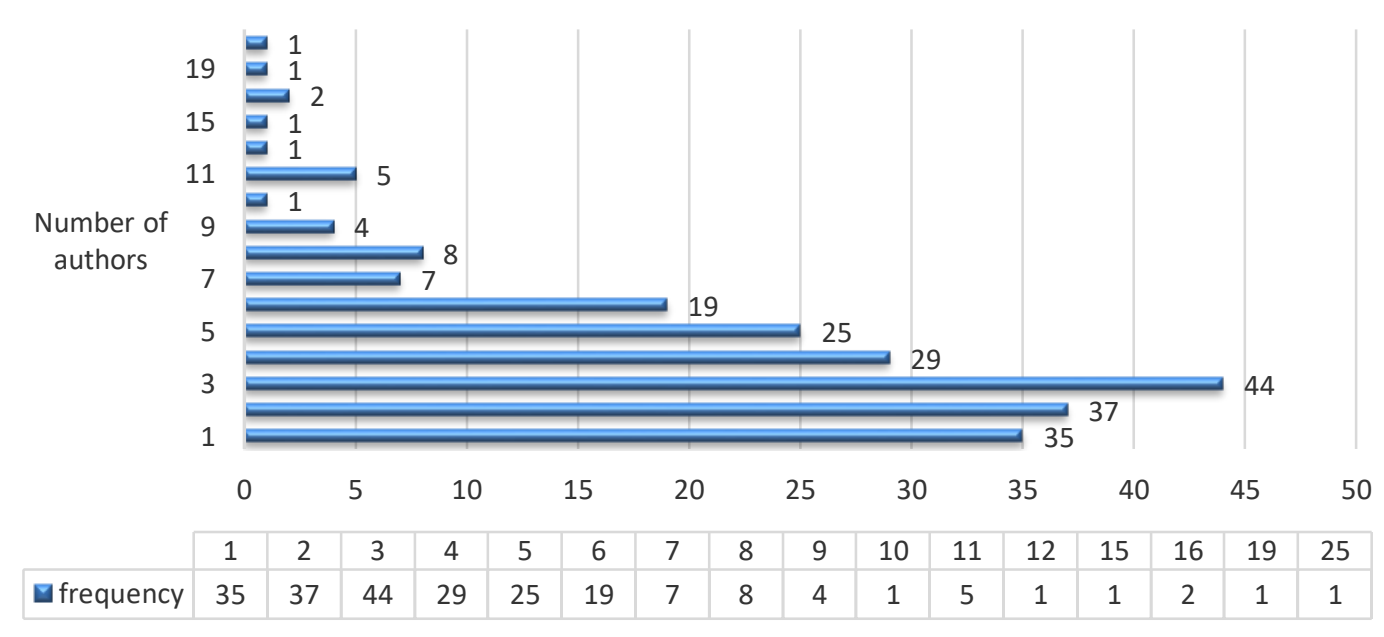

Figure 3. Number of authors scatter plot

In Figure 3, it was observed that $20 \%$ of the studies conducted for distance learning activities during the pandemic period have three authors $(n=44)$, about $17 \%(n=37)$ have two authors, and about $16 \%(n=35)$ have single authors. In addition, it is noteworthy that approximately 5\% of the studies have 10 or more authors. It is understood from the graph that the average number of authors per article is about four. This indicates that the studies were conducted largely on a collaborative basis. 


\section{R.Q.3. Distribution of articles by the number of pages}

Another variable examined in the content analysis was the number of pages of the studies. According to the findings, approximately half of the studies had a page number of 10 or less. The findings of the number of pages are given in Figure 4.

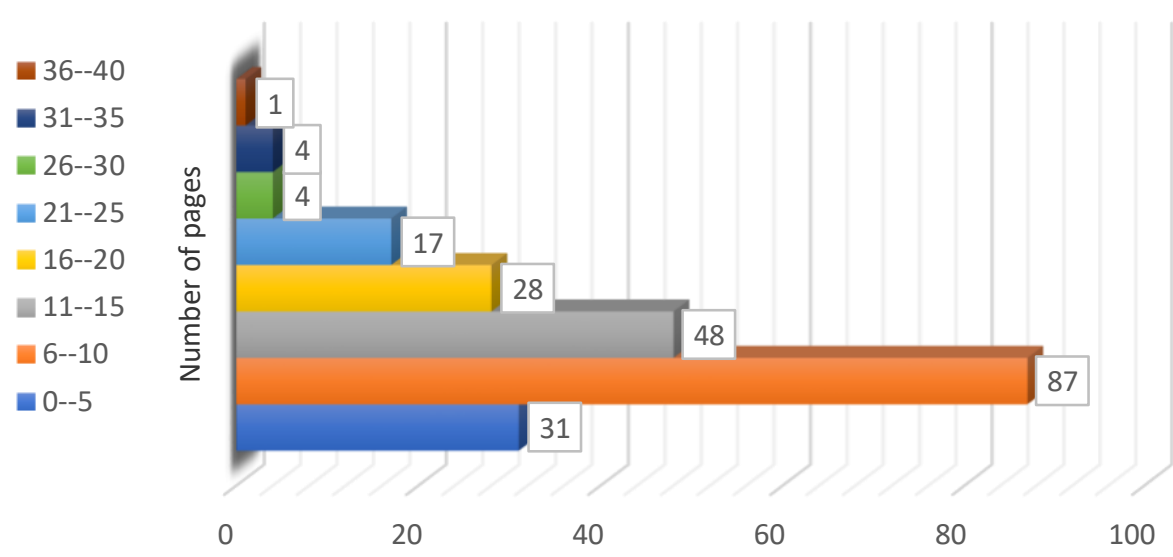

Figure 4. Number of pages scatter plot

In Figure 4, it is seen that about $14 \%$ of the studies conducted for distance learning activities during the pandemic period had 0-5 pages, about 40\% had 6-10 pages, and about 22\% had 11-15 pages. In addition, $12 \%$ of studies have a page number of 21 and above. Considering the entire chart, the average number of pages per work is calculated as 12 . This situation can be seen as a result of the researchers focusing more on literature review studies since the subject is new.

\section{R.Q.4. Distribution of articles by country of publication}

As a result of bibliometric analysis, the distribution of articles by country was examined. When the publishing countries are examined, it shows a wide distribution on the geography of the world. The distribution of the articles by the countries in which they are published is given in Figure 5.

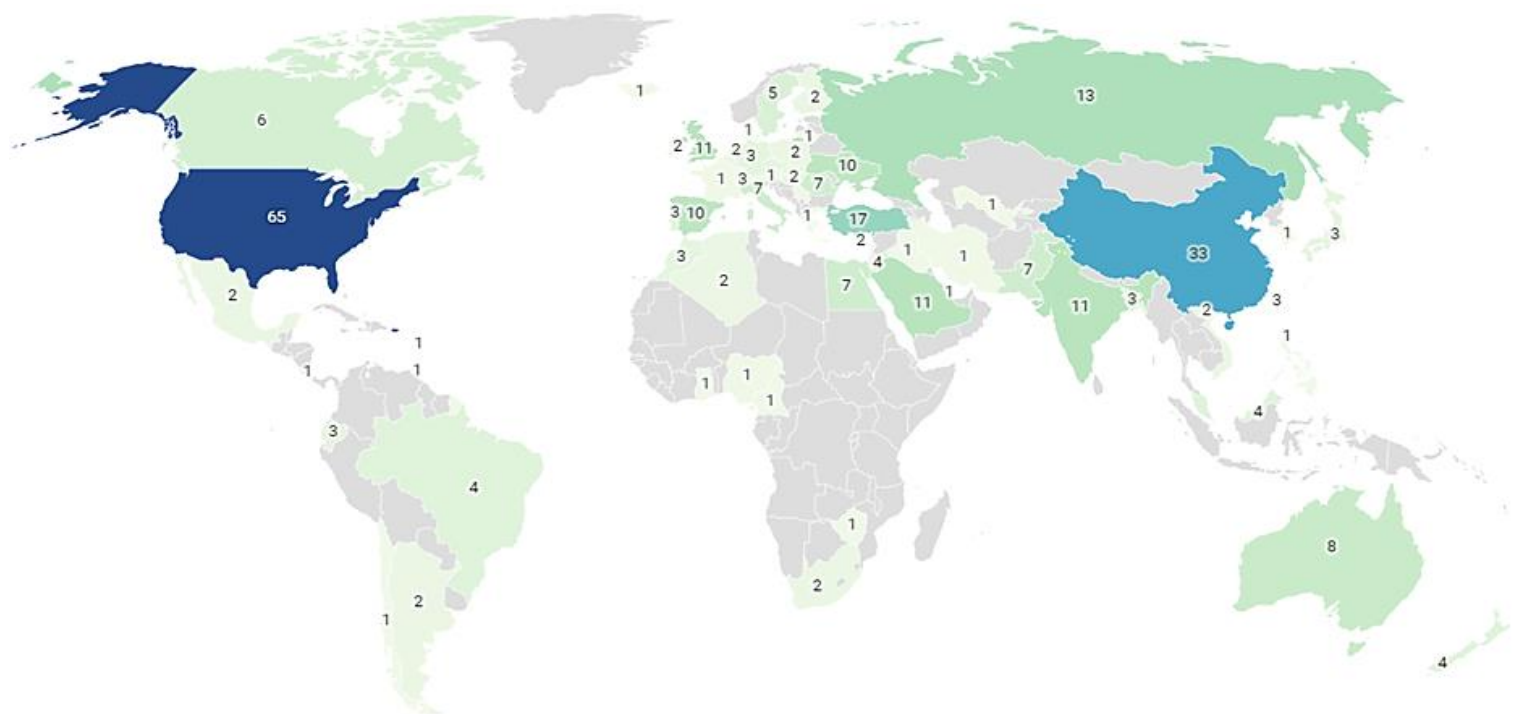

Figure 5. Distribution of articles by country of publication 
As a result of the analysis, it was seen that articles were produced in 70 different countries in total. It can be said that studies have been carried out in countries where the pandemic has spread in different continents of the world. The top 10 countries with the highest number of publications are also determined and shown in Table 2.

Table 2.

Top 10 countries with the highest number of publications

\begin{tabular}{lr}
\hline Country & Documents \\
\hline USA & 65 \\
China & 33 \\
Turkey & 17 \\
Russia & 13 \\
England & 11 \\
Saudi Arabia & 11 \\
India & 11 \\
Spain & 10 \\
Ukraine & 10 \\
Australia & 8 \\
\hline
\end{tabular}

When Table 2 is examined, the countries with the highest number of publications are listed as USA ( $\mathrm{n}=65$ ), China $(n=33)$, Turkey $(n=17)$, Russia $(n=13)$ and England $(n=11)$. It is seen that approximately $45 \%$ of the publications are published by the first two countries. In addition, the top 10 countries with the most citations are given in Table 3.

Table 3.

Top 10 countries with the most citations

\begin{tabular}{lr}
\hline Country & Citations \\
\hline China & 158 \\
USA & 149 \\
England & 93 \\
Spain & 72 \\
New Zealand & 69 \\
Netherlands & 64 \\
Australia & 62 \\
Japan & 54 \\
Taiwan & 54 \\
Cyprus & 54 \\
\hline
\end{tabular}

In Table 3, the most cited countries are China $(n=158)$, USA $(n=149)$, England $(n=93)$, Spain $(n=72)$ and New Zealand $(n=69)$, respectively. China and the United States took the top two places in the ranking of the most cited countries, as well as in the ranking of the most published countries. It is just that they have changed their position in the rankings. The total number of citations of these two countries constitutes approximately $30 \%$ of all citations. In addition, Turkey, Russia, Saudi Arabia, India and Ukraine, which are among the countries with the highest number of publications, could not be among the top 10 countries with the highest number of citations. Contrary to this situation, New Zealand, Netherlands, Japan, Taiwan and Cyprus managed to rank among the top 10 countries with the most citations. 


\section{R.Q.5. Most used keywords in studies}

For the bibliometric analysis of the most used keywords, "Co-occurrence" was selected as the analysis type and "Authors keywords" was marked as the unit. In this context, a total of 685 keywords were found from the data set. Among these keywords, the minimum threshold number of 3 was selected and the bibliometric analysis $($ Clusters $=8$, Links $=193$, Total link strength "TLS" $=376$ ), which revealed a total of 39 keywords, is given in Figure 6.

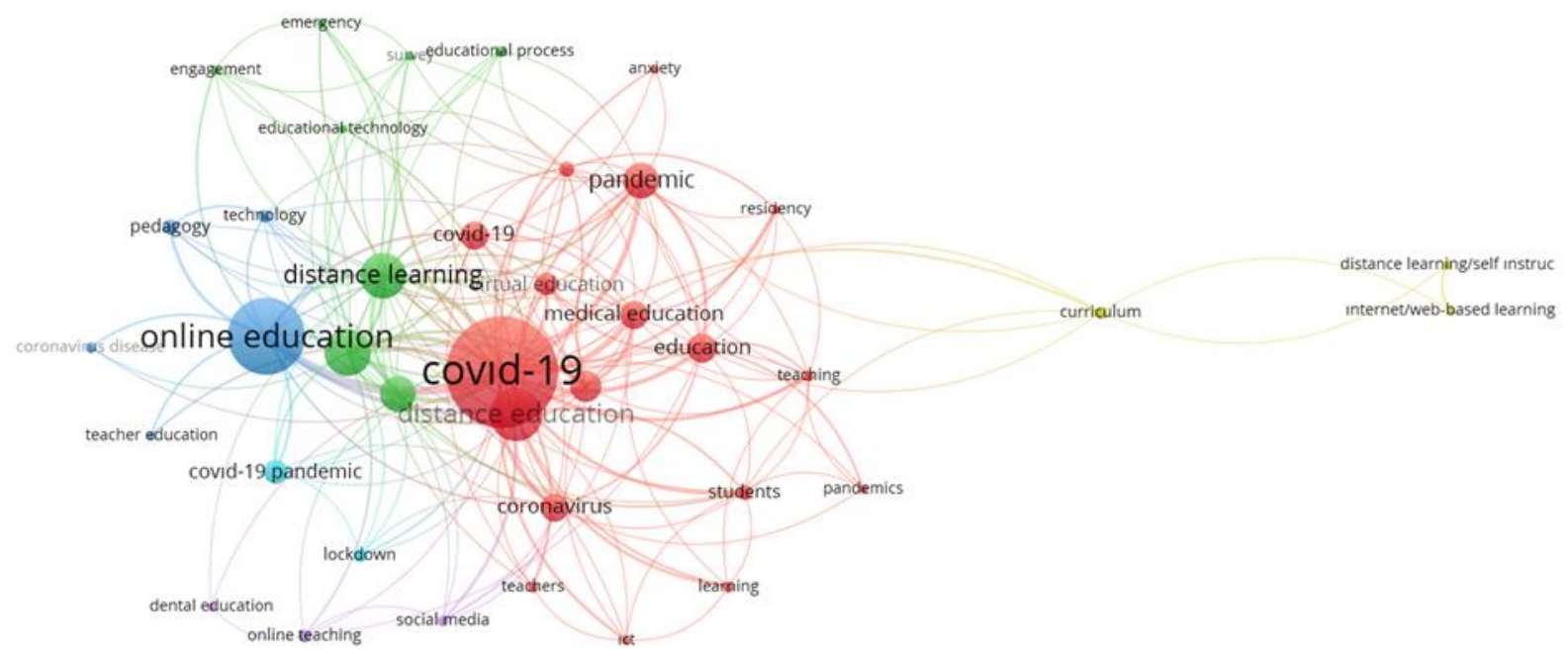

Figure 6. Analysis results of publications by keywords

When Figure 6 is examined, the keywords used in the studies listed as "covid-19" (Occurences"Oc"=74), "online education" (Oc=46), "distance education" (Oc=29), "online learning" (Oc=25), "distance learning" $(\mathrm{Oc}=24)$ and "pandemic" $(\mathrm{Oc}=18)$. These were followed by e-learning, education, medical education, coronavirus and technology expressions. When the keywords of the publications are examined, it is seen that approximately $61 \%(\mathrm{n}=135)$ use words such as Covid-19 and evocative pandemic or coronavirus. In addition, it is seen that keywords such as anxiety, curriculum, telehealth and dental education are less preferred in bibliometric analysis. However, a word cloud belongs to the summary section of the articles were presented.

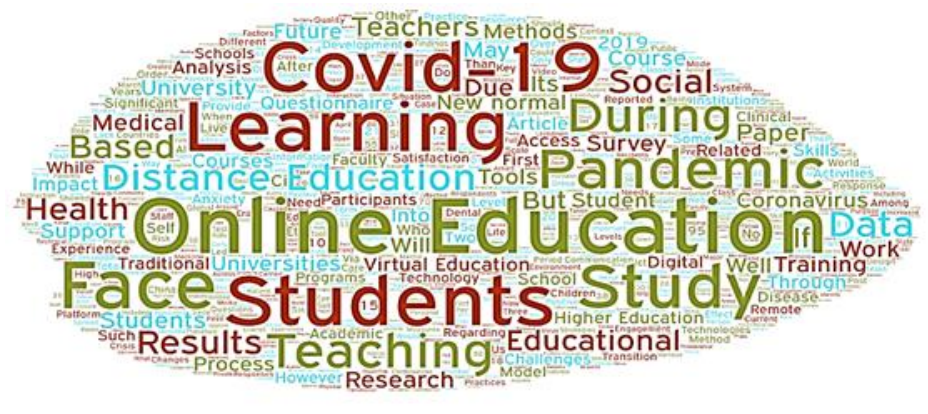

Figure 7. Word cloud for the summary section of the studies

As seen in Figure 7, expressions such as covid-19, pandemic, online education, distance education, learning stand out as the most used words in the summary. These keywords are in line with the keywords shown in the bibliometric analysis. In other words, the keywords in Figure 6 are similar to the word cloud of the summary section of the articles in Figure 7. 


\section{R.Q.6. Most cited authors (Citation and Co-citation analysis)}

In the bibliometric analysis of the most cited authors, "Citation" was chosen as the analysis type and "Authors" was marked as the unit. The "Minimum number of documents of an author" value is set to 2 and the "Minimum number of citations of an author" value to 0 . As a result of the elections, the analysis result of 35 authors is shown in Figure 8 (Items $=35$, Cluster $=35$; Link $=0$ ).

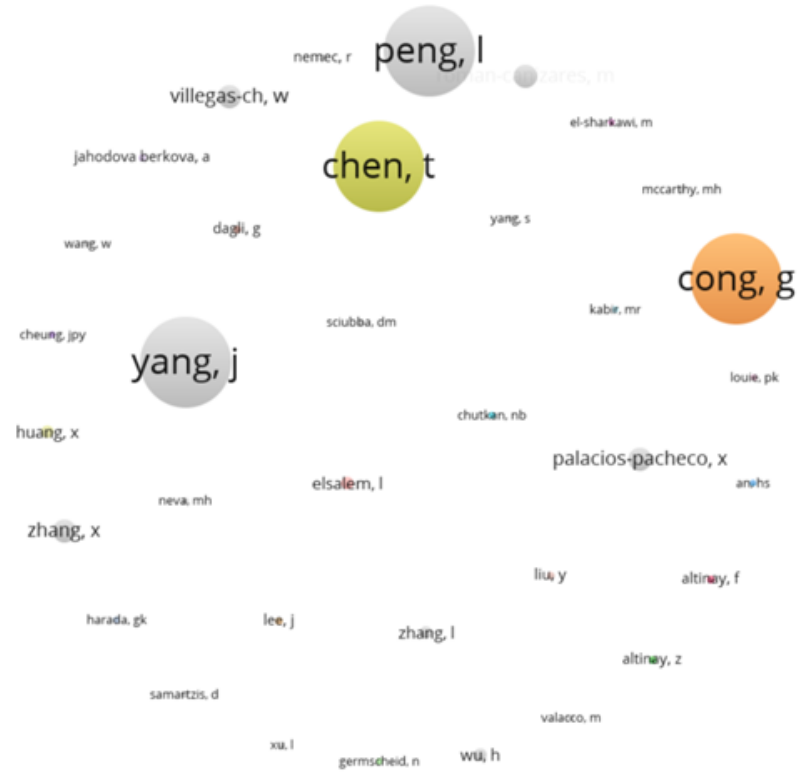

Figure 8. Most cited authors (Citation analysis).

In the above figure, the most cited authors (Citation analysis) are listed as Chen, Cong, Peng, Yang (35 citations). These are followed by Palacios, Roman, Villegas, Zhang (5 citations). However, the co-citation analysis of the most cited authors in the reviewed studies is given in Figure 9 (Items $=48$, Clusters $=8$, Links $=308$ ).

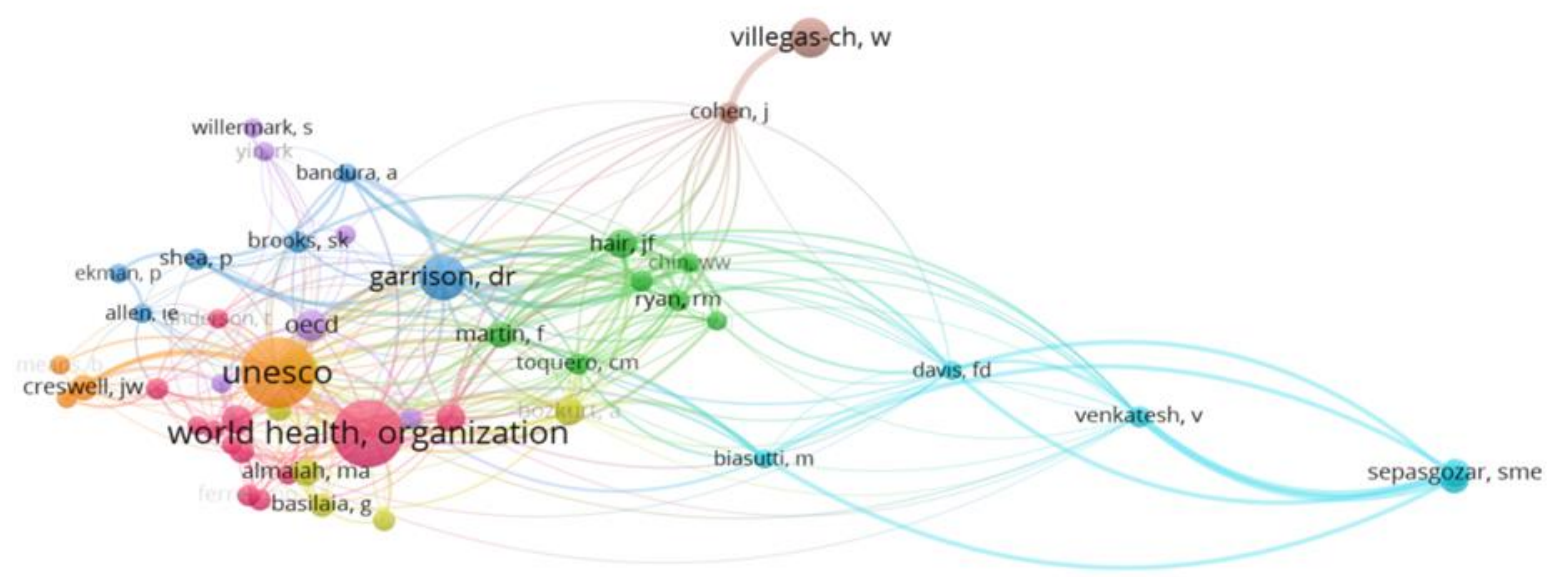

Figure 9. Most cited authors (Co-citation analysis).

Co-citation analysis aims to determine the impact of studies by counting the number of citations that occur together. Accordingly, co-citation analysis results are listed as UNESCO (39 citations), WHO (36 citations), Garrison (20 citations), Villegas (17 citations), Hodges (16 citations) and OECD (12 citations). Efforts to clarify the situation can be seen as the main reason for citing pandemic reports by organizations such as UNESCO, WHO and OECD. 


\section{R.Q.7. Co-authorship analysis}

Although there is no link between the authors citing each other in the citation analysis, the co-authorship analysis is based on the direct link between the two authors. In other words, co-authorship analysis is used to evaluate collaboration between different authors (Göksu et al., 2021; Öztürk, 2020). In the bibliometric analysis carried out in this context, "Co-authorship" was chosen as the analysis type and "Authors" as the analysis unit. As a result of the co-authorship analysis in the studies, 880 authors exceeded the threshold value (threshold =2). For each of the 880 authors, the total strength of co-authorship links with other authors was calculated. 24 authors with the highest total connection power (TLS) were selected for the visualization map. However, it has been observed that 12 of them are interconnected. As a result of the co-authorship analysis, the visualization map of the authors who are connected is given in Figure 10 (Items $=12$, Cluster $=1$, Link $=66$, TLS $=132$ ).

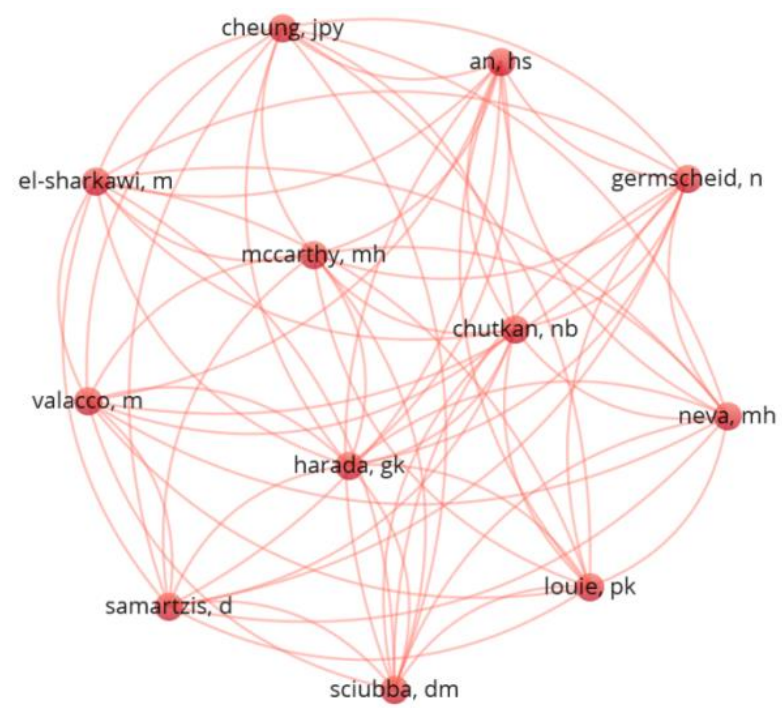

Figure 10. Co-authorship analysis for the reviewed studies

Co-authorship analysis for the studies is given in Figure 10. When this figure was examined, it was seen that only one cluster was formed about the authors who carried out the studies. It was determined that the number of studies of 12 authors in the current cluster was 2 and their TLS values were 22.

\section{R.Q.8. Most cited journals and Most published journal (Citation and Co-Citation)}

In the bibliometric analysis made for the most cited journals, "Citation" was chosen as the analysis type and "Sources" as the analysis unit. The "Minimum number of documents of an author" value was set to 2 and the "Minimum number of citations of an author" value to 0 . As a result of the elections, the analysis result of 33 journals can be seen in Figure 11 (Items $=33$, Cluster $=32$; Link $=1$ ). 


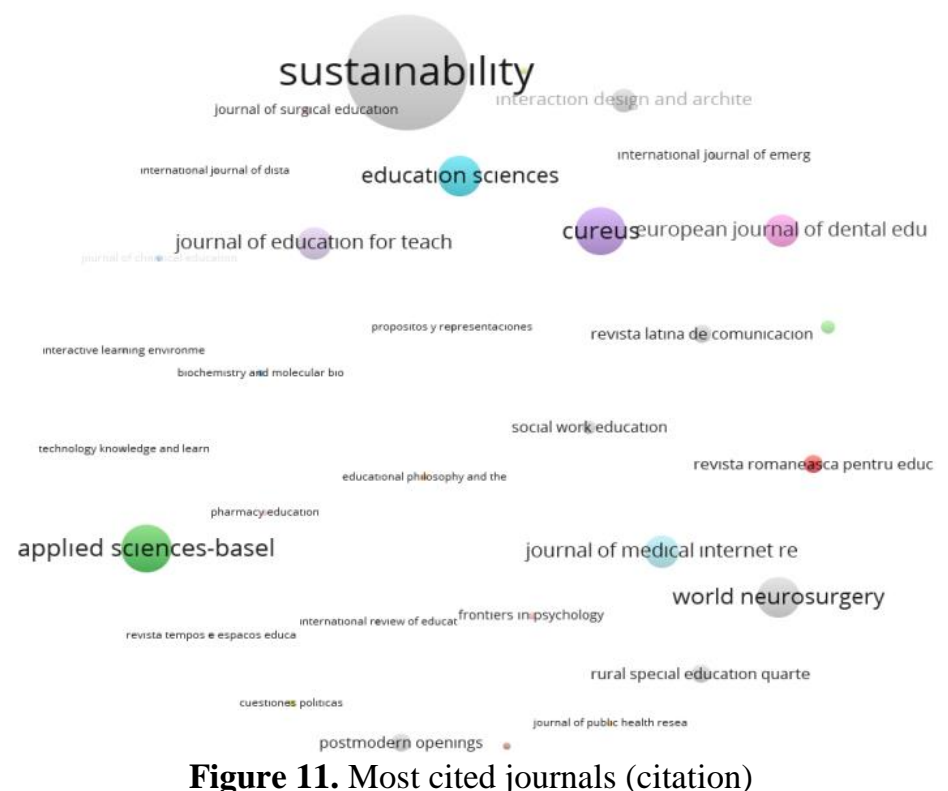

When Figure 11 is examined, the first four journals with the most citations are listed as Sustainability (Citation=30, Document=13), Applied sciences (Citation=10, Document=3), Cureus (Citation=10, Document=2) and Education sciences (Citation=8, Document=7). In addition, "co-citation" as the analysis type and "cited sources" as the analysis unit was selected for the co-citation analysis of the most cited journals in the reviewed studies. The minimum number of citations of a source was set at 10 and the number of sources to be selected was automatically stated to be 71. The results of the Most cited journals (CoCitation) analysis were as in Figure 12 (Items $=86$, Cluster $=7$, Links $=1214$ and TLS $=8667$ ).

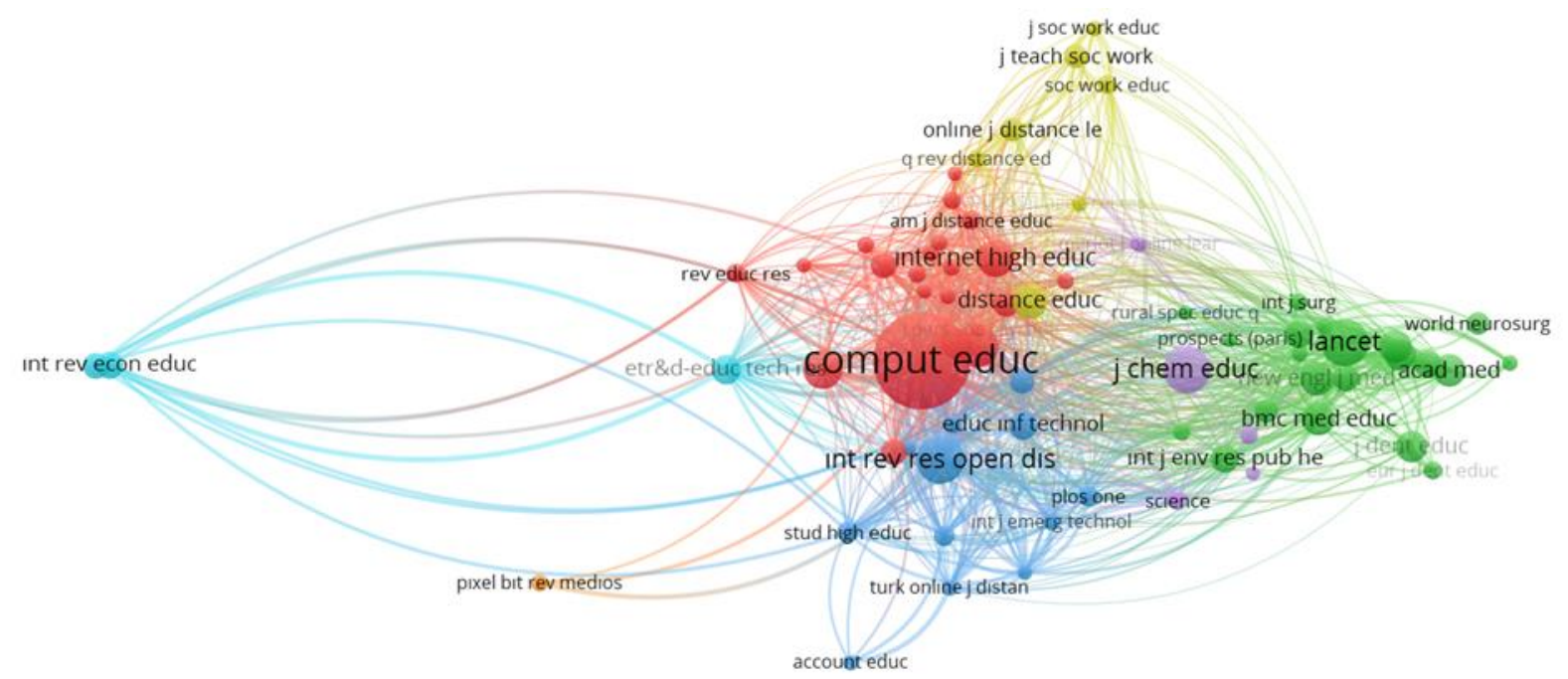

Figure 12. Most cited journals (co-citation)

When Figure 12 is examined, the co-citation numbers of journals are listed as Computers \& Education (125 co-citations), International Review of Research in Open and Distributed Learning (48 co-citations), Lancet (47 co-citations), Journal of Chemical Education (47 co-citations), Sustainability (40 co-citations) and The Internet and Higher Education (34 co-citations). Another variable examined with bibliometric analysis was the journals in which the studies were published. The top 10 journals that publish the most about distance education activities during the pandemic period were given in Table 4. 


\section{Table 4.}

Top 10 journals with the most articles published

\begin{tabular}{ll}
\hline Journals & f \\
\hline Revista Romaneasca Pentru Educatie Multidimensionala & 14 \\
Sustainability & 13 \\
Education Sciences & 7 \\
Educational Technology Research and Development & 5 \\
Interaction Design and Architectures & 4 \\
Journal of Education for Teaching & 4 \\
Applied Sciences Basel & 3 \\
Cureus & 3 \\
European Journal of Dental Education & 3 \\
International Journal of Emerging Technologies in Learning & 3 \\
\hline
\end{tabular}

When Table 4 is examined, the most published journals were Revista Romaneasca Pentru Educatie Multidimensionala $(n=14)$, Sustainability $(n=13)$, Education Sciences $(n=7)$ and Educational Technology Research and Development $(\mathrm{n}=5)$. The sum of the values in this table corresponds to approximately $50 \%$ of the articles evaluated within the scope of the study. Besides, the number of studies published in the first two journals corresponds to $45 \%$ of the total value in the table.

\section{R.Q.9. Methodological trends of the studies}

\section{Research methods:}

In terms of the methods used, the studies were subjected to content analysis. In this context, it was seen that the majority of the studies were carried out by quantitative research methods. The findings obtained regarding the method by which the studies were carried out are given in Figure 13.

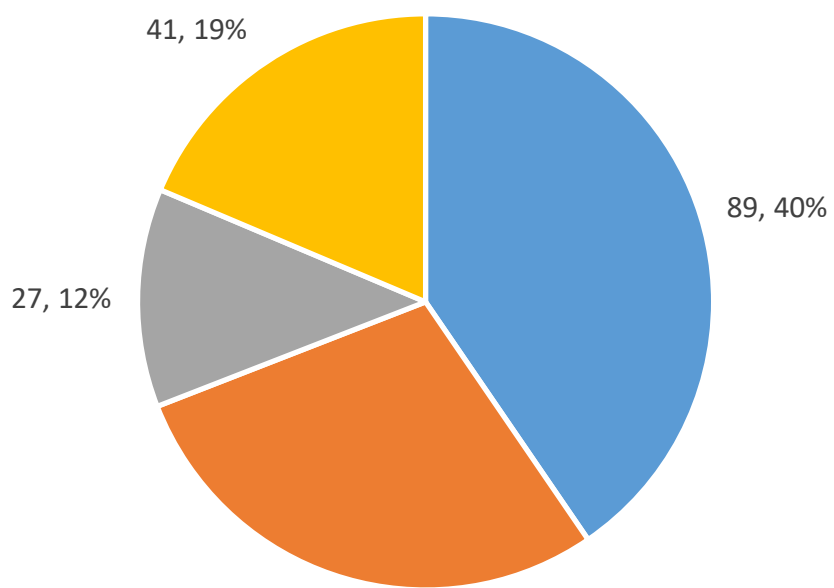

$63,29 \%$

- Quantitative $\quad$ Qualitative $=$ Mixed $\square$ Review

Figure 13. Research methods scatter plot

When Figure 13 is examined, it was seen that approximately $40 \%$ of the studies were quantitative, $29 \%$ were qualitative, $19 \%$ were reviews and finally, $12 \%$ were mixed studies. When the graph was examined, 
it was seen that qualitative-based studies and quantitative-based studies had similar values to each other. In addition, the high rate of use of survey studies can be shown as the reason why quantitative research methods are more than other methods.

\section{Sample distribution:}

The sample numbers were examined within the scope of the content analysis carried out in the review. In this context, it was observed that samples with a sample size of less than 100 are mostly preferred. The detailed graphic of the sample sizes used in the studies is given in Figure 14.

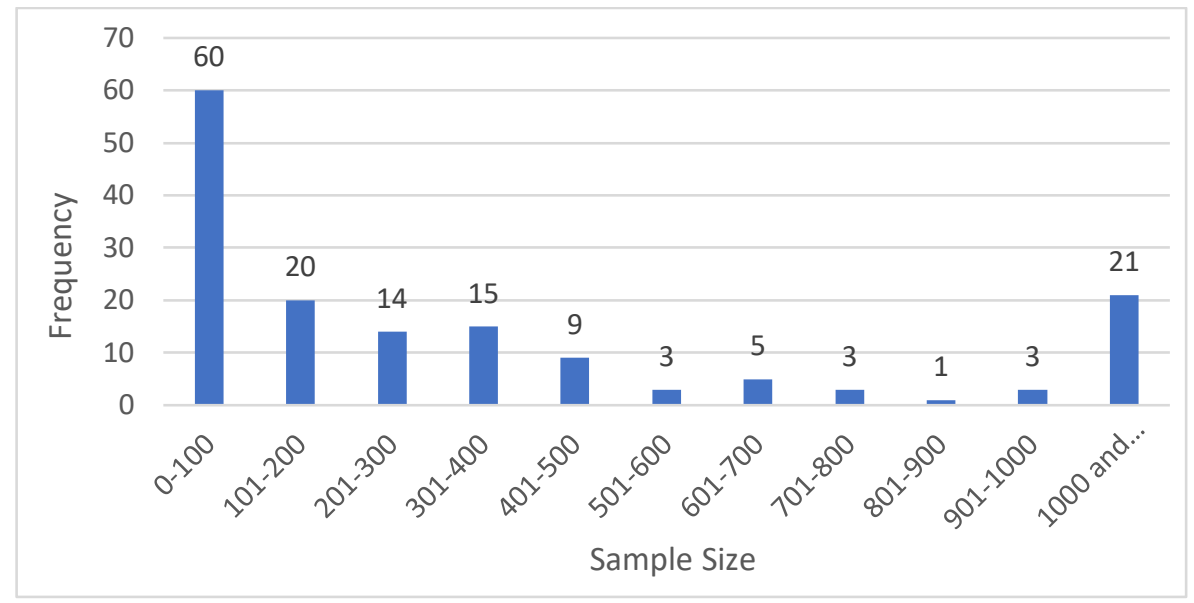

Figure 14. Distribution of publications by sample size

When Figure 14 was examined, the first three most preferred sample sizes in studies were listed as; the 0100 range is ranked as 39\% $(\mathrm{n}=60), 1000+14 \%(\mathrm{n}=21)$, and $100-200$ range $13 \%(\mathrm{n}=20)$. The high sample size of 101 and above $(61 \%)$ indicates that the number of studies that collected data with the questionnaire is high. Another variable examined within the scope of the study is the distribution of the participants in which the sample was formed. The studies mostly focused on higher education level and it was observed that the participants were university students and lecturers. Detailed information about the sample groups used in the study is given in Table 5.

\section{Table 5.}

Distribution of the sample groups used in the studies

\begin{tabular}{ll}
\hline Sample Group & f \\
\hline University Student & 78 \\
Instructor & 25 \\
Teacher & 18 \\
Document & 13 \\
K12 student & 12 \\
Doctor & 9 \\
Assistant & 5 \\
Parent & 4 \\
Adult & 3 \\
Child & 2
\end{tabular}


$\begin{array}{ll}\text { Faculty } & 2 \\ \text { Out of sector } & 2 \\ \text { Others } & 10\end{array}$

When the participants in the samples are examined according to the table above, university students with $42 \%$, lecturers with $14 \%$ and teachers with $10 \%$ take the first three places. The least number of participants were parents, adults, children, faculty and non-sector participants. By examining the overall table, it can be stated that the studies are mostly carried out for students and teachers at different education levels.

\section{Data collection tools:}

Another variable examined within the scope of content analysis is data collection tools. In this context, it is seen that surveys are generally used as data collection tools in studies. Detailed findings on data collection tools are given in Table 6.

\section{Table 6.}

Data collection tools used in studies

\begin{tabular}{ll}
\hline Data collection tool & f \\
\hline Survey & 105 \\
Interview form & 39 \\
Document analysis form & 29 \\
Observation form & 12 \\
Scale & 9 \\
Test / Quizz / Exam & 9 \\
Internet comments & 4 \\
Document review & 3 \\
Workshop / Panel & 3 \\
Content analysis form & 3 \\
Log records & 2 \\
Video & 2 \\
Learning diaries & 1 \\
\hline
\end{tabular}

When Table 6 is examined, the top three most preferred data collection tools in studies; surveys (47\%), interview forms (17\%) and document analysis forms (13\%). However, it has been observed that different data collection tools such as learning logs, videos, log recordings are also used. It is seen that the researchers, who cannot face the sample group due to the pandemic, prefer to collect data through online surveys intensively.

\section{Data analysis methods:}

The data analysis methods covered within the scope of content analysis were examined under three titles. While the quantitative analysis was examined in two dimensions, descriptively and predictively, qualitative 
analysis was examined in one dimension. The findings obtained as a result of the analysis are given in Figure 15 in detail.

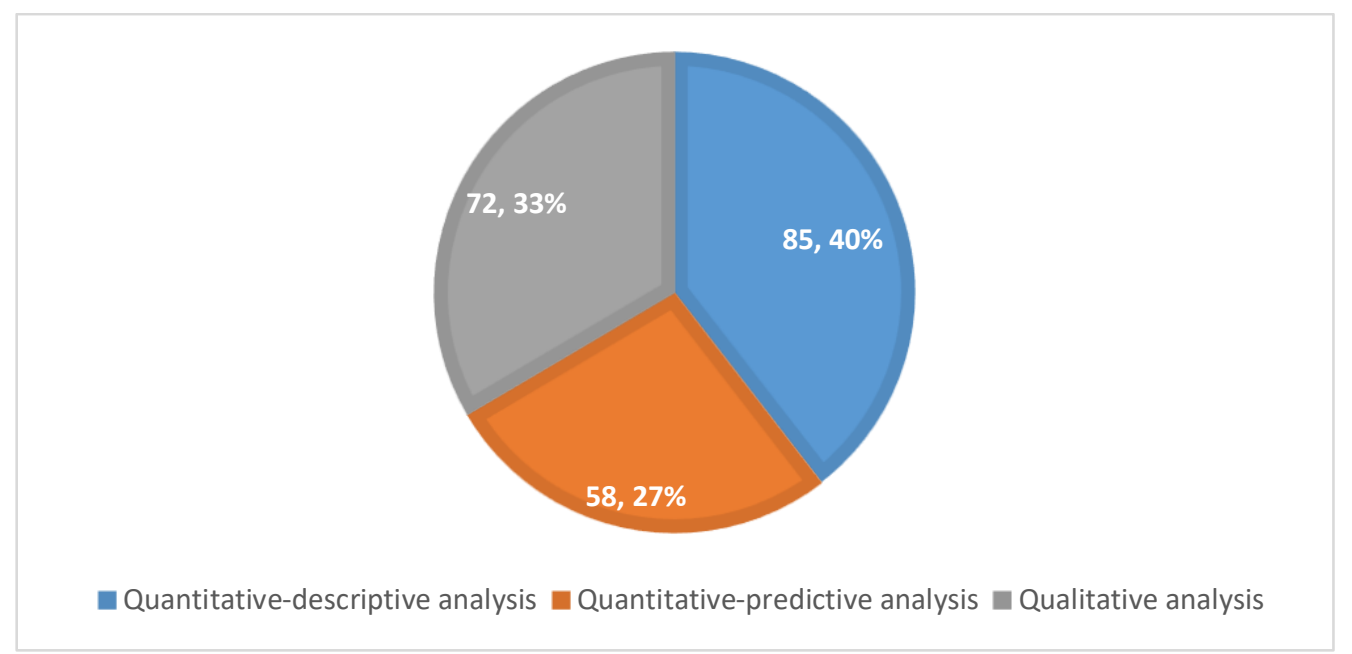

Figure 15. Data analysis methods

When Figure 15 is examined, it is seen that the quantitative-descriptive analysis method is used mostly with $40 \%$. In the second place, qualitative analysis method was preferred with $33 \%$. It is seen that the least preferred analysis method is the quantitative-predictive analysis method with $27 \%$. Since the method preferred in academic studies, data collection tools and data analysis methods are determined in an interconnected way, the findings given in this graph are parallel to the method and data collection tool.

\section{Discussions}

The purpose of this study is to reveal the profile of the studies conducted for distance education activities in the Covid-19 period. In this context, 220 articles obtained from the WoS database were subjected to content and bibliometric analysis. In this section, the findings obtained as a result of data analysis are discussed in parallel with the research questions. When the articles on distance education during the pandemic are examined, it is seen that the studies are mainly published in the last quarter of 2020. This situation can be seen as a natural result of the writing and publishing process of the articles. Considering that the pandemic started in March and considering the average publication time of scientific articles (Umut \& Şencan, 2016; Özkara, 2019), it seems normal that the number of publications will increase towards the end of the year. This finding is in parallel with the finding obtained in the study by Aristovnik et al. (2020) that "the number of publications has increased by approximately $60 \%$ after May and continues rapidly." On the other hand, it contradicts the finding obtained in the study conducted by Homolak et al., (2020) that "there were too many publications at the beginning of the pandemic period." Yet, according to the findings obtained within the scope of the study, it is seen that the number of studies conducted in the first months of the pandemic period is less than the other months. When the number of authors of the studies conducted within the scope of distance education activities during the epidemic period is examined, it is seen that they are generally written by more than one author. In addition, it can be stated that they were prepared in cooperation with multiple authors in order to compare the practices in different countries. Bozkurt et al. (2020), with 39 authors representing 31 countries from six continents in total, Elsayes et al. (2021), in which 25 authors from different countries worked together, can be cited as an example of this situation. In addition, the findings of the study conducted by Akl et al. (2020) are similar to the findings of the present study.

Considering the countries where the analyzed studies were published, it is seen that the countries with the highest number of publications and citations are the USA and China. This is in line with the number of academic activities carried out by these countries throughout the year. When the report published by World 
Bank (2018) and the results of the article published by Ortas (2018) are examined, it is seen that the top two countries with the most academic publications are the USA and China. In particular, a period of about 20 years between 1996 and 2017 was evaluated in the study carried out by Ortaş (2018). The fact that the number of publications in other countries is lower than the number of publications in China may be due to the virus's origin (Chahrour et al., 2020). This can also be seen as an indication that Chinese scientists are doing their work in the fight against the virus in order to share their publications with scientists all over the world and to inform them about the conditions. Similar findings were also found in studies conducted by Akl et al. (2020), Al-Zaman (2020) and Dehghanbanadaki et al. (2020).

One of the variables examined within the scope of the review is key words. As a result of bibliometric analysis, covid-19, online education, distance education, online learning, distance learning, pandemic, medical education keywords were most commonly used in the articles. Findings obtained within the study, Aristovnik et al., (2020), Chen, Huang, et al. (2020), Fan et al. (2020) With the findings obtained in the studies carried out by Kaya and Erbay (2020), the pandemic shows similarities in terms of identifying keywords. Nevertheless Rodrigues et al. (2020) similar to the majority of the findings obtained in the study. The most cited author order examined within the scope of bibliometric analysis is Chen, Cong, Peng, Yang, Palacios, Roman, Villegas, Zhang. It is seen that these authors have done their work together and have the same number of citations. This situation coincides with the thought that most of the studies carried out during the process were co-authored (Al-Zaman, 2020; Dehghanbanadaki et al., 2020; Kaya \& Erbay, 2020). A co-citation analysis was conducted to find the number of citations that occurred together alongside the most cited authors. Here, it is seen that the common citations of organizations such as UNESCO, WHO and OECD are higher than others. In the co-authorship analysis based on cooperation between different authors, it was seen in the findings that only a cluster of 12 authors was formed.

Another one of the findings obtained in the study is the most common list of journals and 33 journals were analyzed in this context. These journals are listed as Sustainability, Applied Sciences, Cureus and Education Sciences. While Sweileh (2021) listed the journal "Nurse Education in Practice" in the top 10, in the findings of this review, it was not included in the top 10. However, the journals with the most common citations are listed as Computers \& Education, International Review of Research in Open and Distributed Learning, Lancet, Journal of Chemical Education and Sustainability. Darsono et al. (2020) and Kaya \& Erbay (2020) found that Lancet journal is among the top 10 in the common citation list, similar to this review. In addition, the journals that publish the most articles on the subject are listed as Revista Romaneasca Pentru Educatie Multidimensionala, Sustainability, Education Sciences and Educational Technology Research and Development. Al-Zaman (2020) included Cureus magazine among the top 10 journals with the highest number of publications, as in the findings obtained in this review.

As a result of the content analysis carried out within the scope of the study, it was seen that $40 \%$ of the studies were carried out by quantitative methods, $12 \%$ by mixed and $58 \%$ by qualitative methods. Qualitative studies aimed at defining the new process that started with the pandemic and quantitative survey studies conducted to determine the views of stakeholders on the process may have caused the distribution of the methods in this way. In contrast to the current study, Maulana (2020) concluded that the number of quantitative studies is higher than the number of qualitative studies.

In the sample distribution, which is another variable examined, it was observed that studies were conducted mainly with university students, lecturers and teachers, while the most preferred sample size was found to be between 0-100. This situation may have been caused by the researchers' preference for convenient sampling. Studies in which sample numbers greater than 100 are used constitute $61 \%$ of all studies, and online survey studies can be shown as the biggest reason for this situation. As a matter of fact, when the results of the content analysis performed for the data collection tools are examined, it is seen that the most preferred data collection tool in the studies is the questionnaire, in line with the above statement. The questionnaire was followed by the interview form and the document analysis form, respectively. As a result of the content analysis performed within the scope of the review, it is seen that the most preferred data 
analysis method in the studies is quantitative-descriptive analysis and quantitative-predictive analysis. With the adverse conditions of the pandemic, researchers generally preferred online studies rather than face-toface studies. In scientific research, the research method suitable for the purpose of the study and the sample, data collection tool and data analysis methods ideal for this method are determined. In this case, it influenced the preferred research method, sample size, data collection tools and data analysis methods in a chain manner (Karasar, 2017). In line with the method used in the study conducted by Maulana (2020), data collection tools and data analysis methods continued in an interrelated way.

\section{Conclusion and Suggestions}

Findings obtained in this study are limited to the publications in the WoS database. In the review of the studies on distance education during the pandemic period, the following results were obtained:

- The most commonly used keywords in distance education studies during the pandemic process are Covid-19, Pandemic, Online education, Distance education, Learning.

- According to the other result obtained within the scope of the study, the USA and China are the countries that publish the most articles and receive the most citations for distance education in the pandemic period.

- It has been concluded that the studies conducted for distance education during the pandemic period are mainly co-authored studies.

- Within the scope of the study, it was concluded that the most cited authors were Chen, Cong, Peng, Yang, and in the co-citation analysis, UNESCO, WHO and Garrison.

- The most cited journals within the scope of the study are listed as Sustainability, Applied sciences, Cureus and Education sciences, and according to the co-citation analysis of the journals, Computers \& Education, International Review of Research in Open and Distributed Learning, Lancet and Journal of Chemical Education.

- According to another result obtained within the scope of the study, it has been observed that qualitative and quantitative-based studies take close values. In addition, it was concluded that university students were generally used as samples, questionnaires as data collection tools, and quantitative-descriptive analysis method as the data analysis method.

In the light of the findings obtained in this study, the following suggestions can be made to future researchers;

- Increase the sample size by including studies in different databases

- Increase the number of such bibliometric studies in other fields.

- Increase the number of studies in other educational levels besides higher education

- Comparative studies were found to be insufficient in the scope of the review. Increasing the number of studies in different countries or different fields on this subject,

- After the pandemic is over, it is recommended to carry out studies that will photograph the entire Covid-19 period.

\section{References}

Adom, D. (2020). Cultural and educational implications of the covid-19 global pandemic in Ghana. Sciences, 9(3). http://doi.org/10.17583/rimcis.2020.5416 
Akl, E. A., Meho, L. I., Farran, S. H., Nasrallah, A. A., \& Ghandour, B. (2020). The Pandemic of the Covid19 literature: A bibliometric analysis running title: bibliometric analysis of the covid-19 literature.

Al-Zaman, M. (2020). Bibliometric analysis of Covid-19 literature. Science Editing, 8(1). https://doi.org/10.6087/kcse.230

Aristovnik, A., Ravšelj, D., \& Umek, L. (2020). A bibliometric analysis of Covid-19 across science and social science research landscape. Sustainability, 12(21), 9132. https://doi.org/10.3390/su12219132

Artsın, M. (2020). Bir metin madenciliği uygulamasi: Vosviewer [A text mining application: Vosviewer]. Eskişehir Technical University Journal of Science and Technology B - Theoretical Sciences, 8(2), 344-354.

Aydın, Ç. G. (2020). Covid-19 salgını sürecinde öğretmenler [Teachers during the Covid-19 outbreak]. TEDMEM. Retrieved from https://tedmem.org/covid-19/covid-19-salgini-surecinde-ogretmenler

Bozkurt, A. (2020). Koronavirüs (Covid-19) pandemi süreci ve pandemi sonrası dünyada eğitime yönelik değerlendirmeler: Yeni normal ve yeni eğitim paradigması [Coronavirus (Covid-19) pandemic process and education in the world evaluations towards: New normal and new education paradigm]. Journal of Open Education Applications and Research, 6(3), 112-142. Retrieved from https://dergipark.org.tr/en/pub/auad/issue/56247/773769

Bozkurt, A., Jung, I., Xiao, J., Vladimirschi, V., Schuwer, R., Egorov, G., ... \& Paskevicius, M. (2020). A global outlook to the interruption of education due to Covid-19 pandemic: Navigating in a time of uncertainty and crisis. Asian Journal of Distance Education, 15(1), 1-126. Retrieved from http://www.asianjde.org/ojs/index.php/AsianJDE/article/view/462

Chahrour, M., Assi, S., Bejjani, M., Nasrallah, A. A., Salhab, H., Fares, M. Y., \& Khachfe, H. H. (2020). A bibliometric analysis of Covid-19 research activity: A call for increased output. Cureus. https://doi.org/10.7759/cureus.7357.

Chen, Y., Guo, Y.-B., Guo, R., Chen, X.-F., Chang, G.-H., Li, X., Hao, L.-Y., Sun, Z.-R., \& Zhang, Z.-L. (2020). Visual analysis of coronavirus disease 2019 (Covid-19) studies based on bibliometrics. China Journal of Chinese Materia Medica, 45(10), 2239-2248. https://doi.org/10.19540/j.cnki.cjcmm.20200320.501

Chen, H., Huang, X., \& Li, Z. (2020). A content analysis of Chinese news coverage on Covid-19 and tourism. Current Issues in Tourism, 1-8. https://doi.org/10.1080/13683500.2020.1763269

Chertakova, E. M., Lapshova, A. V., Bystrova, N. V., Smirnova, Z. V., \& Bulaeva, M. N. (2020). Special features of vocational training institutions in the context of pandemics. Cuestiones Políticas, 38.

Cohen, L., Manion, L., \& Morrison, K. (2007). Research methods in education (6th ed.). New York, NY: Routledge. 
Darsono, D., Rohmana, J. A., \& Busro, B. (2020). Against Covid-19 pandemic: Bibliometric assessment of world scholars' international publications related to Covid-19. Jurnal Komunikasi Ikatan Sarjana Komunikasi Indonesia, 5(1), 75-89. https://doi.org/10.25008/jkiski.v5i1.356.

Dehghanbanadaki, H., Seif, F., Vahidi, Y., Razi, F., Hashemi, E., Khoshmirsafa, M., \& Aazami, H. (2020). Bibliometric analysis of global scientific research on Coronavirus (Covid-19). Medical Journal of the Islamic Republic of Iran, 34(1), 354-362. https://doi.org/10.34171/mjiri.34.51

Elizabeth Noor Coutts, C., Buheji, M., Ahmed, D., Abdulkareem, T., Buheji, A., Buheji, B., ... \& Perepelkin, N. (2020). Emergency remote education in Bahrain, Iraq, and Russia During the Covid19 pandemic: A comparative case study. Human Systems Management, 1-21. https://doi.org/10.3233/HSM-201097

Elsayes, K. M., Marks, R. M., Kamel, S., Towbin, A. J., Kielar, A. Z., Patel, P., ... \& Hsieh, P. (2021). Online liver imaging course; pivoting to transform radiology education during the SARS-coV-2 pandemic. Academic radiology, 28(1), 119-127. https://doi.org/10.1016/j.acra.2020.10.001

Falkingham, L., \& Reeves, R. (1998). Context analysis-A technique for analysing research in a field, applied to literature on the Management of R\&D at the section level. Scientometrics, 42(2), 97-120. https://doi.org/10.1007/bf02458351

Fan, J., Gao, Y., Zhao, N., Dai, R., Zhang, H., Feng, X., ... \& Bao, S. (2020). Bibliometric analysis on Covid-19: A comparison of research between English and Chinese studies. Frontiers in Public Health, 8, 477. https://doi.org/10.3389/fpubh.2020.00477

Fiş Erümit, S. (2021). The distance education process in $\mathrm{K}-12$ schools during the pandemic period: Evaluation of implementations in Turkey from the student perspective. Technology, Pedagogy and Education, 1-20. https://doi.org/10.1080/1475939X.2020.1856178

Giovannella, C., Marcello, P., \& Donatella, P. (2020). The effects of the Covid-19 pandemic on Italian learning ecosystems: The school teachers' Perspective at the steady state. ID\&A Interaction Design \& Architecture(s), 45, 264-286.

Göksu, I., Koçak, O., Gündüz, A., \& Göktaş, Y. (2021). Instructional design studies between 1975 and 2019: A bibliometric analysis. International Journal of Online Pedagogy and Course Design, 11(1), 73-92. https://doi.org/10.4018/IJOPCD.2021010105

Göktaş, Y., Küçük, S., Aydemir, M., Telli, E., Arpacık, Ö., Yıldırım, G., \& Reisoğlu, İ. (2012). Türkiye'de eğitim teknolojileri araştırmalarındaki eğilimler: 2000-2009 dönemi makalelerinin içerik analizi [Educational technology research trends in Turkey: A content analysis of the 2000-2009 decade]. Educational Sciences: Theory \& Practice, 12(1), 177-199. 
Golinelli, D., Nuzzolese, A. G., Boetto, E., Rallo, F., Greco, M., Toscano, F., \& Fantini, M. P. (2020). The impact of early scientific literature in response to Covid-19: A scientometric perspective. In medRxiv. https://doi.org/10.1101/2020.04.15.20066183

Gonçalves, S. P., Sousa, M. J., \& Pereira, F. S. (2020). Distance learning perceptions from higher education students-The case of Portugal. Education Sciences, $10(12), \quad 374$. https://doi.org/10.3390/educsci10120374

Hamann, K., Glazier, R. A., Wilson, B. M., \& Pollock, P. H. (2020). Online teaching, student success, and retention in political science courses. European Political Science, 1-13. https://doi.org/10.1057/s41304-020-00282-X

Hamidah, I., Sriyono, \& Hudha, M. N. (2020). A bibliometric analysis of Covid-19 research using Vosviewer. Indonesian Journal of Science and Technology. https://doi.org/10.17509/ijost.v5i2.24522

Hodges, C., Moore, S., Lockee, B., Trust, T., \& Bond, A. (2020). The difference between emergency remote teaching and online learning. Educause Review, 3, 1-15.

Homolak, J., Kodvanj, I., \& Virag, D. (2020). Preliminary analysis of Covid-19 academic information patterns: A call for open science in the times of closed borders. Scientometrics, 124(3), 2687-2701. https://doi.org/10.1007/s11192-020-03587-2

Hossain, M. M. (2020). Current status of global research on novel coronavirus disease (Covid-19): A bibliometric analysis and knowledge mapping. Flo00Research, 9, 374. https://f1000research.com/articles/9-374

Hugar, J. G., Bachalapur, M. M., \& Kumara, P. (2020). Covid-19 pandemic disease: A bibliometric study. Library Philosophy and Practice, 1-21.

Kambhampati, S. B. S., Vaishya, R., \& Vaish, A. (2020). Unprecedented surge in publications related to Covid-19 in the first three months of pandemic: A bibliometric analytic report. Journal of Clinical Orthopaedics and Trauma, 11(Suppl 3), S304-S306. https://doi.org/10.1016/j.jcot.2020.04.030

Karasar, N. (2017). Bilimsel araştırma yöntemleri [Scientific research methods] (35th ed.). Ankara: Nobel Publishing.

Kaya, M., \& Erbay, E. (2020). Global trends of the researches on Covid-19: A bibliometric analysis via VOSviewer. Journal of Ankara Health Sciences, 9(2), 201-216. Retrieved from https://dergipark.org.tr/en/pub/ausbid/issue/59001/817925

Kim, J. (2020). Learning and teaching online during Covid-19: Experiences of student teachers in an early childhood education practicum. International Journal of Early Childhood, 52(2), 145-158. https://doi.org/10.1007/s13158-020-00272-6 
Liberati, A., Altman, D. G., Tetzlaff, J., Mulrow, C., Gøtzsche, P. C., Ioannidis, J. P., ... \& Moher, D. (2009). The PRISMA statement for reporting systematic reviews and meta-analyses of studies that evaluate health care interventions: Explanation and elaboration. Journal of clinical epidemiology, 62(10), e1-e34.

Lou, J., Tian, S. J., Niu, S. M., Kang, X. Q., Lian, H. X., Zhang, L. X., \& Zhang, J. J. (2020). Coronavirus disease 2019: A bibliometric analysis and review. European Review for Medical and Pharmacological Sciences, 24(6), 3411-3421. https://doi.org/10.26355/eurrev_202003_20712

Marti-Parreno, J., Mendez-Ibanez, E., \& Alonso-Arroyo, A. (2016). The use of gamification in education: A bibliometric and text mining analysis. Journal of Computer Assisted Learning, 32(6), 663-676. https://doi.org/10.1111/jcal.12161

Maulana, N. (2020). Research trends in marketing science before Covid-19 outbreak: A literature review. Management \& Marketing. Challenges for the Knowledge Society, 15(1), 514-533.

McBurney, M. K., \& Novak, P. L. (2002). What is bibliometrics and why should you care? In Proceedings. IEEE international professional communication conference (pp. 108-114). IEEE.

Nemec, R., Jahodova Berkova, A., \& Hubalovsky, S. (2020). Identification elements symmetry in teaching informatics in Czech secondary school during the Covid-19 outbreak from the perspective of students. Symmetry, 12(11), 1768. https://doi.org/10.3390/sym12111768

Ortaş, İ. (2018). Bilimsel yayınlar yönünden Türkiye'nin dünyadaki yeri nedir? [What is the place of Turkey in terms of scientific publications in the world?] INDIGO. Retrieved from https://indigodergisi.com/2018/07/bilimsel-yayinlar-turkiye-yeri/

Özkara, B. Ö. (2019). ULAKBIM'de dizinlenen eğitim bilimleri dergilerinde 2017 yılında yayımlanan makalelerin çözümlenmesi [Analysis of the articles published in 2017 in educational sciences journals indexed in ULAKBİM]. Ankara University Journal of Faculty of Educational Sciences, 52(2), 469-494. https://doi.org/10.30964/auebfd.424104

Öztürk, R. (2020). The trends of marketing literature during the Covid-19 pandemic: A review with bibliometric analysis. OPUS International Journal of Society Researches, 16 (Special Issue), 32513273. https://doi.org/10.26466/opus.788120

Patton, M. Q. (2014). Qualitative research and evaluation methods. (Trans. Eds. M. Butun \& SB Demir). Ankara: Pegem Academy.

Rodrigues, M., Franco, M., \& Silva, R. (2020). Covid-19 and disruption in management and education academics: Bibliometric mapping and analysis. Sustainability, 12(18), 73-62. https://doi.org/10.3390/su12187362 
Samson. P. (2020). The coronavirus and class broadcasts. Educause review magazine. Retrieved from https://er.educause.edu/blogs/2020/3/the-coronavirus-and-class-broadcasts

Selçuk, Z., Palanc1, M., Kandemir, M., \& Dündar, H. (2014). Eğitim ve bilim dergisinde yayınlanan araştırmaların eğilimleri: İçerik analizi [Tendencies of the researches published in education and science journal: Content analysis]. Education and Science, 39(173).

Smith, N. (2020). "Ten Tips from an Online Educator”. The Tyee Magazine. https://thetyee.ca/ Analysis/2020/04/01/Online-Educator-Ten-Tips/. Erişim Tarihi: 03.03.2021.

Sweileh, W. M. (2021). Global research activity on e-learning in health sciences education: A bibliometric analysis. Medical Science Educator, 1-11. https://doi.org/10.1007/s40670-021-01254-6

TTF 2030. (2020). Response to the Covid-19 outbreak - Call for action on teachers. Retrieved from http://www.teachersforefa.unesco.org/v2/index.php/en/ressources/file/470-response-to-the-covid19-outbreak-call-for-action-on-teachers

Umut, A. L., \& Şencan, İ. (2016). Bilimsel iletişimin dikenli yolları: makalelerin yayın süreci üzerine bir değerlendirme [Thorny roads of scholarly communication: An evaluation on the publication process of articles]. Turkish Librarianship, 30(3), 449-470.

UNESCO. (2020). Covid-19 educational disruption and response. Retrieved from https://en.unesco.org/covid19/educationresponse

Wang, C., Wang, W., \& Wu, H. (2020). Association between medical students' prior experiences and perceptions of formal online education developed in response to Covid-19: A cross-sectional study in China. BMJ open, 10(10), e041886. http://dx.doi.org/10.1136/bmjopen-2020-041886

World Bank. (2018). Scientific and technical journal articles. Retrieved from https://data.worldbank.org/indicator/IP.JRN.ARTC.SC

Yavuz, M., Kayalı, B., Balat, Ş., \& Karaman, S. (2020). Salgın sürecinde Türkiye'deki yükseköğretim kurumlarının acil uzaktan öğretim uygulamalarının incelenmesi. Milli Ĕ̆itim Dergisi, 49(1), 129154.

Zamfir, A. M. (2020). Educational resilience in pandemic times and potential impacts on inequalities: The case of Romania. Revista Romaneasca pentru Educatie Multidimensionala, 12(2Sup1), 182-187. https://doi.org/10.18662/rrem/12.2Sup1/305

Zhai, F., Zhai, Y., Cong, C., Song, T., Xiang, R., Feng, T., Liang, Z., Zeng, Y., Yang, J., Yang, J., \& Liang, J. (2020). Research progress of coronavirus based on bibliometric analysis. International Journal of Environmental Research and Public Health, 17(11), 3766. https://doi.org/10.3390/ijerph17113766. 
Zhou, Y., \& Chen, L. (2020). Twenty-year span of global coronavirus research trends: A bibliometric analysis. International Journal of Environmental Research and Public Health, 17(9). https://doi.org/10.3390/ijerph17093082 